\title{
Rock Art, Burials, and Habitations: \\ Caves in East Kalimantan
}

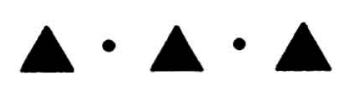

JEAN-MICHEL CHAZINE

THE DISCOVERY OF CHARCOAL DRAWINGS in a rock shelter by Luc-Henri Fage and a caving team on a trek through Kalimantan from Pontianak to Samarinda in 1988 initiated an extensive program of ethnoarchaeological survey. Every year since 1992, a Franco-Indonesian team has conducted surveys of caves and rock shelters in East Kalimantan, providing a large set of new data from different periods and greatly enlarging archaeological knowledge of this part of Island Southeast Asia. Caves appear to have been used as habitation locations from late Pleistocene to contemporary periods. The discovery of paddle-impressed pottery decorated with cord, herring-bone, and plaited impressions in the rugged and inaccessible central Müller Range, and dated as early as about 3000 years ago, was a clue that this remotest part of Borneo had been settled in prehistory (Chazine 1995).

It was clearly important to map the distribution of these cave sites in order to establish the geographical range of the pottery makers. Also, because figurative and expressive paintings had been observed in Sarawak caves such as Niah, Gua Sarang, and Sarang (Datan 1993; T. Harrisson 1958; Solheim 1983) and had been generally linked to the late Austronesian period (from ca. 2000 B.P. to perhaps 100 years ago), it was assumed that there were no archaic (pre-Austronesian) paintings there or, more generally, in Borneo (Ballard 1992). However, the unexpected discovery in 1994 north of Sangkulirang of negative handprints associated with very different symbolic and zoomorphic figures cast doubt on this assumption and reoriented investigations (Chazine 1999). Discoveries have included caves with deposits that have yielded domestic and funerary pottery, lithic assemblages, and faunal remains. Around 100 caves and rock shelters have now been located and surveyed in East Kalimantan, many of which have produced evidence that suggests occupation by prehistoric hunter-gatherer communities (Fig. 1). The construction of roads through the primary forest by logging companies has also exposed evidence of open sites, especially on hilltops and along streams, though

Jean-Michel Chazine, Centre de Recherche et de Documentation sur l'Océanie, Maison AsiePacifique, Université de Provence.

Asian Perspectives, Vol. 44, No. 1 (C) 2005 by the University of Hawai'i Press. 


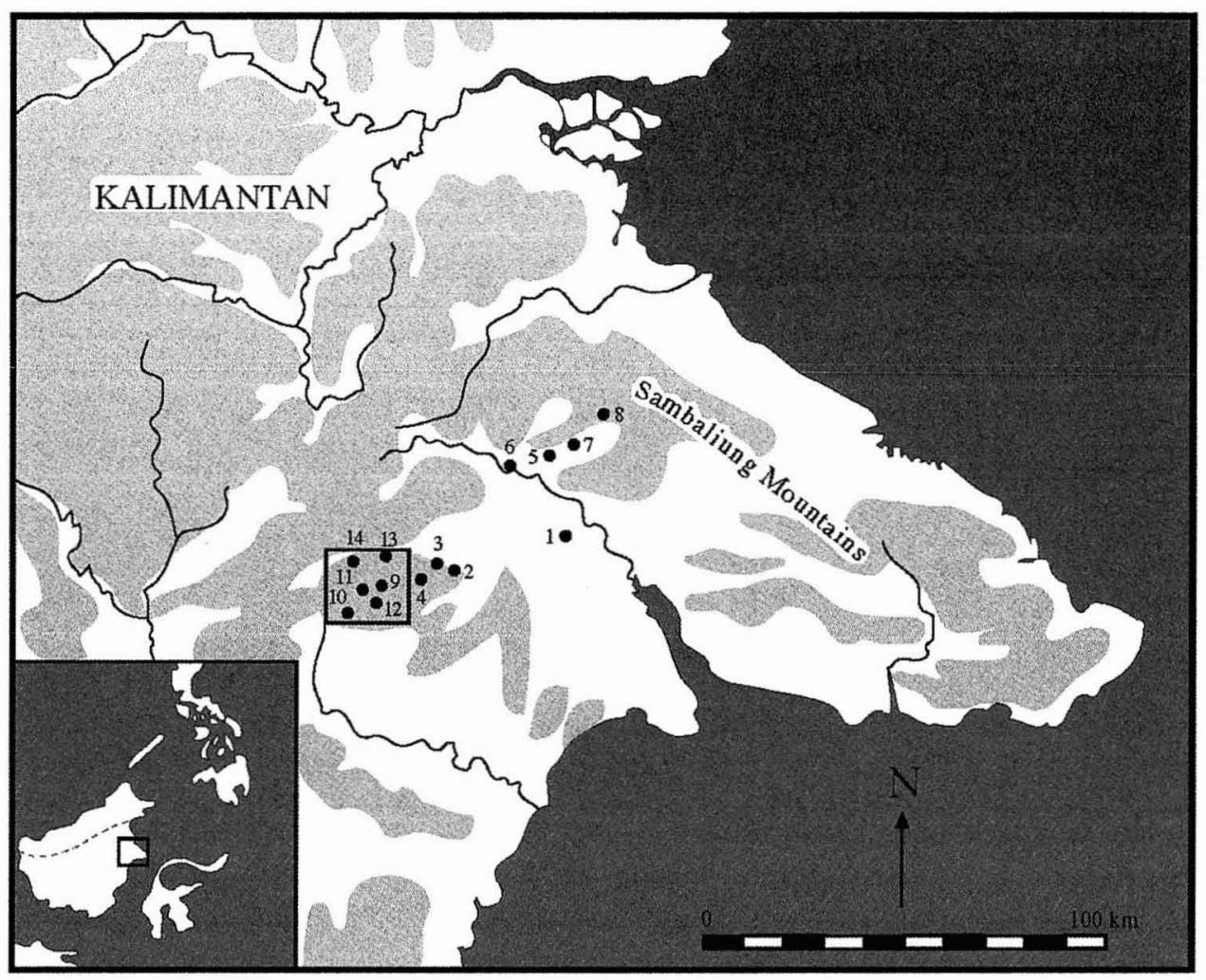

Fig. 1. Caves and rock shelters located in East Kalimantan (ornately decorated sites shown in italics): 1. Gua Mardua; 2. Gua Payau; 3. Gua Kambing; 4. Liang Sara; 5. Alan Bilao; 6. Liang Pelahniran; 7. Ara Raya; 8. Gua Masri; 9. Gua Ilas Kenceng; 10. Gua Tewet, Gua Pindi, Gua Te'et, Gua Ujan, Gua Batu Aji; 11. Gua Tamrin, Gua Mentis, Gua Kayu Sampung, Gua Ilas Kecil, Gua Tangkorak, Gua Kurang Tahu, Gua Ham; 13. Gua Berak, Gua Jufri, Gua Tembus, Gua Sahak; 14. Gua Lungun, Gua Keboboh, Gua Gudang Pecah, Gua Ampir Kosong, Liang Jon. The inset is shown as Figure 2.

these sites consist only of lithic scatters that have not yielded organic remains suitable for ${ }^{14} \mathrm{C}$ dating.

Since 1998, a series of caves and rock shelters has been mapped on and around the upper Bangalon River in the northwest of Samarinda, many of them, especially the remotest and highest caves in karstic outcrops, decorated with stenciled handprints, sometimes with figures superimposed. Recent fieldwork has located an additional 27 new caves and rock shelters along the Marang River (Fig. 2). Of the 27 newly discovered sites, 15 of them contain numerous rock paintings of variable size and state of conservation, the latter reflecting a mixture of geomorphological and biological conditions (Perrette and De Koninck 2001). In one of them, called Gua Tam after our guide's name and property, the motifs, designs, and especially the high number of hand stencils are similar to those observed in Gua Ilas Kenceng cave on the opposite mountain side, though far more numerous.

The caves and rock shelters that have been discovered and surveyed can be 


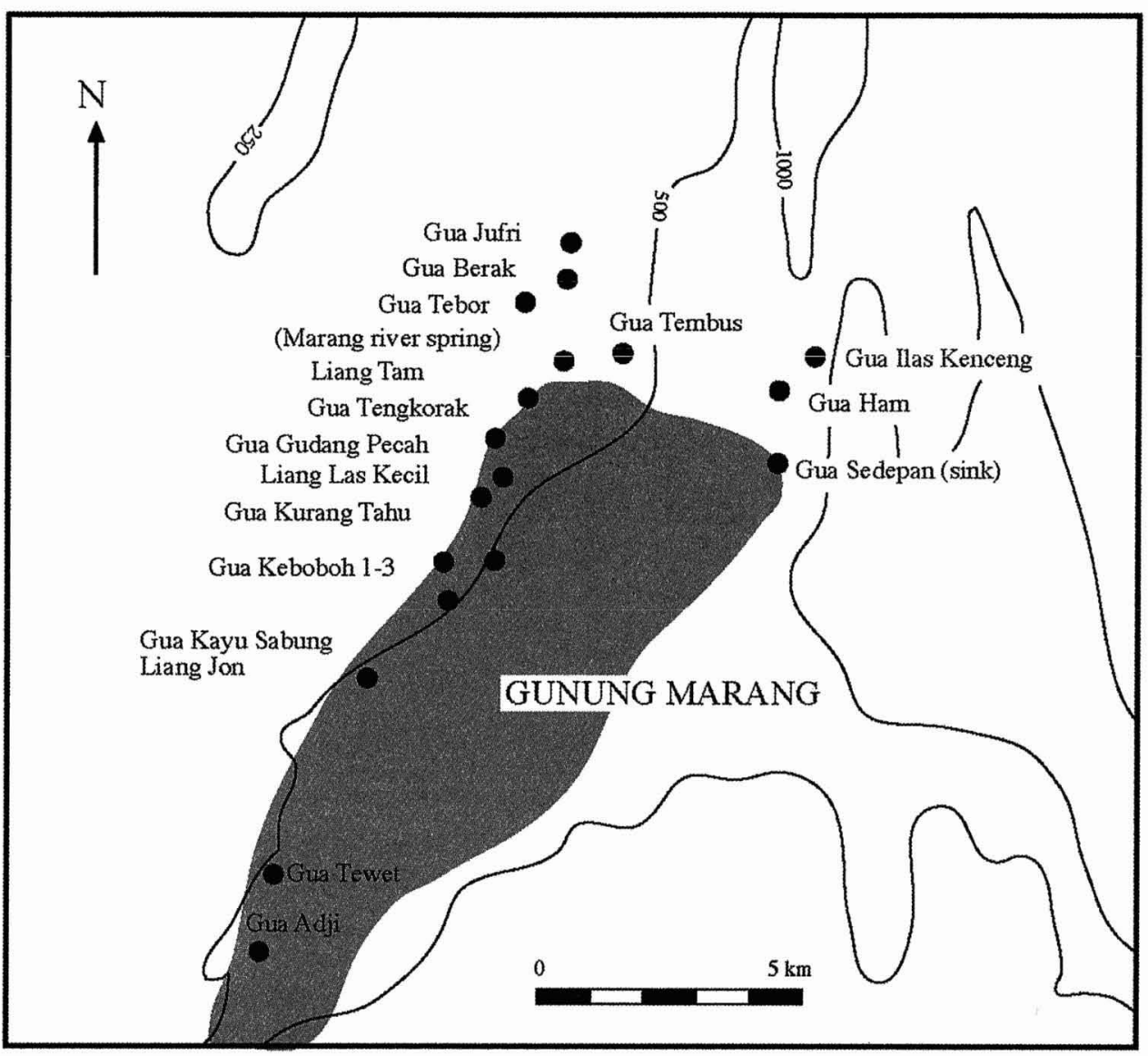

Fig. 2. The location of the principal caves and rock shelters discovered in the Marang River valley.

divided into three categories according to their locations and archaeological characteristics. The first category consists of sites with paintings or other forms of rock art. The second category consists of caves containing evidence especially for funerary activity. The third category consists of sites with evidence for predominantly domestic activities. The three categories differ in their location. The Miocene Limestone of the area has been eroded into three distinct systems of shafts and galleries, at different elevations. In most cases, the rock art sites are found in the upper system, the funerary caves in the middle system, and the domestic sites in the lower system. We noted the same patterning in our previous fieldwork in other parts of East Kalimantan. Of course, there are some exceptions. For example, we found a few caves with paintings, charcoal, and ochre drawings, and sometimes a few chert flakes, that were not in the highest cave system though were accessible only by a short, steep climb. The pottery that seems to have been used mostly for funerary activities was also found sometimes in cracks or crevices in the habitation sites. In some instances these mixtures of material may indicate changes of use, as much cognitive as functional, for example, in the respect 
people had for particular locations, with new people using a cave without the same customs and considerations as earlier generations.

\section{DECORATED CAVES}

Sixteen caves with pictographs or rock art have been located, doubling the number known before this research. The most frequent motif is hand stencils or outlines-some 1500 are now known from the study area (2004), with at least 375 in Gua Ham alone-but they are frequently associated with different motifs drawn inside and on top of them (Fig. 3). Also, there are examples of naturalistic humans and animals. Some of these anthropomorphic and zoomorphic figures are not only in the same caves as the hand stencils, but on the same panels. There is no clear evidence yet regarding the chronological relationships of these different motifs, but it is possible that some of the hand stencils represent the earliest use of the caves. Preliminary analysis by the French CNRS-CEA Research Laboratory of a stalactite flow covering a panel decorated with handprints suggests that the latter must be at least 10,000 years old (Causse and Plagnes 2001), clearly predating the assumed spread of Neolithic or Austronesian people across Southeast Asia 5000-4000 B.P.

There is a great deal of variation in the art produced in the various caves, but the underlying similarities suggest that the human groups who made the art shared a common cultural background. The contrast between underlying similarities, yet individual variations, accord with what we know of hunter-gatherer societies ethnographically in terms of the fluidity of their social relations and the way that bands frequently split, converge, and reform.

Our preliminary observations in the most recent fieldwork suggest that in some locations a primitive "hand stencil" phase may have been followed by a second phase of hand stenciling, when previously drawn stencils or new ones were drawn over or linked together to create more elaborate motifs, as for example in Gua Ilas Kenceng and especially in Gua Tewet (Fig. 4). This joining together and redrawing of hand stencils and their apparent association with human, animal, vegetable, or symbolic motifs may tell real stories. Such associations are repeated in several caves, relationships that contrast strikingly with prehistoric rock art systems elsewhere in the world. The association of hand stencils with highly expressive and dynamic figures, whether or not they are as early as the late Pleistocene as suggested by the stalactite date mentioned above, should certainly predate Neolithic/ Austronesian people if the bovid painted in Gua Ilas Kenceng can be identified on the basis of its horns as Bos javanicus, a species that is thought to have been more or less extinct by the end of the Pleistocene (E. Meijaard pers. comm.). Also, in Gua Tam there is a drawing of what appears to be a large tapir that might represent the giant species that also disappeared at that time (E. Meijaard pers. comm.), and another one was discovered in Liang Karim in 2003.

Close observation of some panels indicates examples of complex linear figures being part of a main motif or scene rather than with hand stencils. In these, hand stencils are separate from and apparently secondary in significance to more explicit figures, in comparison with such motifs in other systems of prehistoric art elsewhere in the world. An example of this is the representation in Gua Jufri (Fig. 5). What is now becoming obvious is that when there are realistic and 


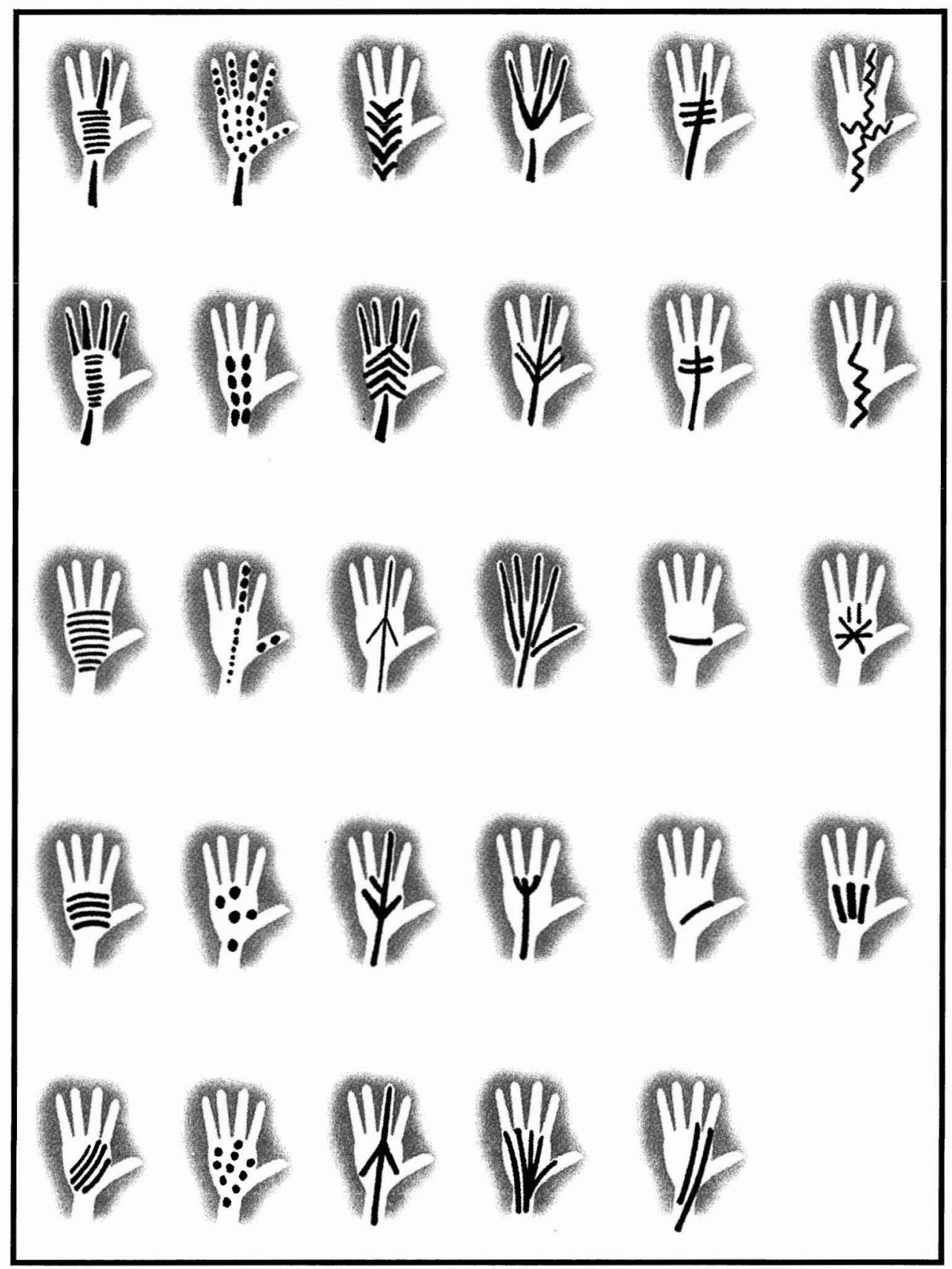

Fig. 3. Gua Tewet: overpainted handprint stencils. (Recorded by L. H. Fage)

figurative motifs upon certain panels, hand stencils become secondary, as everywhere in world rock art. Conversely, when hand stencils are in a majority, they appear to be the most significant motif. This would suggest that hand stencils differentiated in function and meaning depending on their context. Perhaps they 


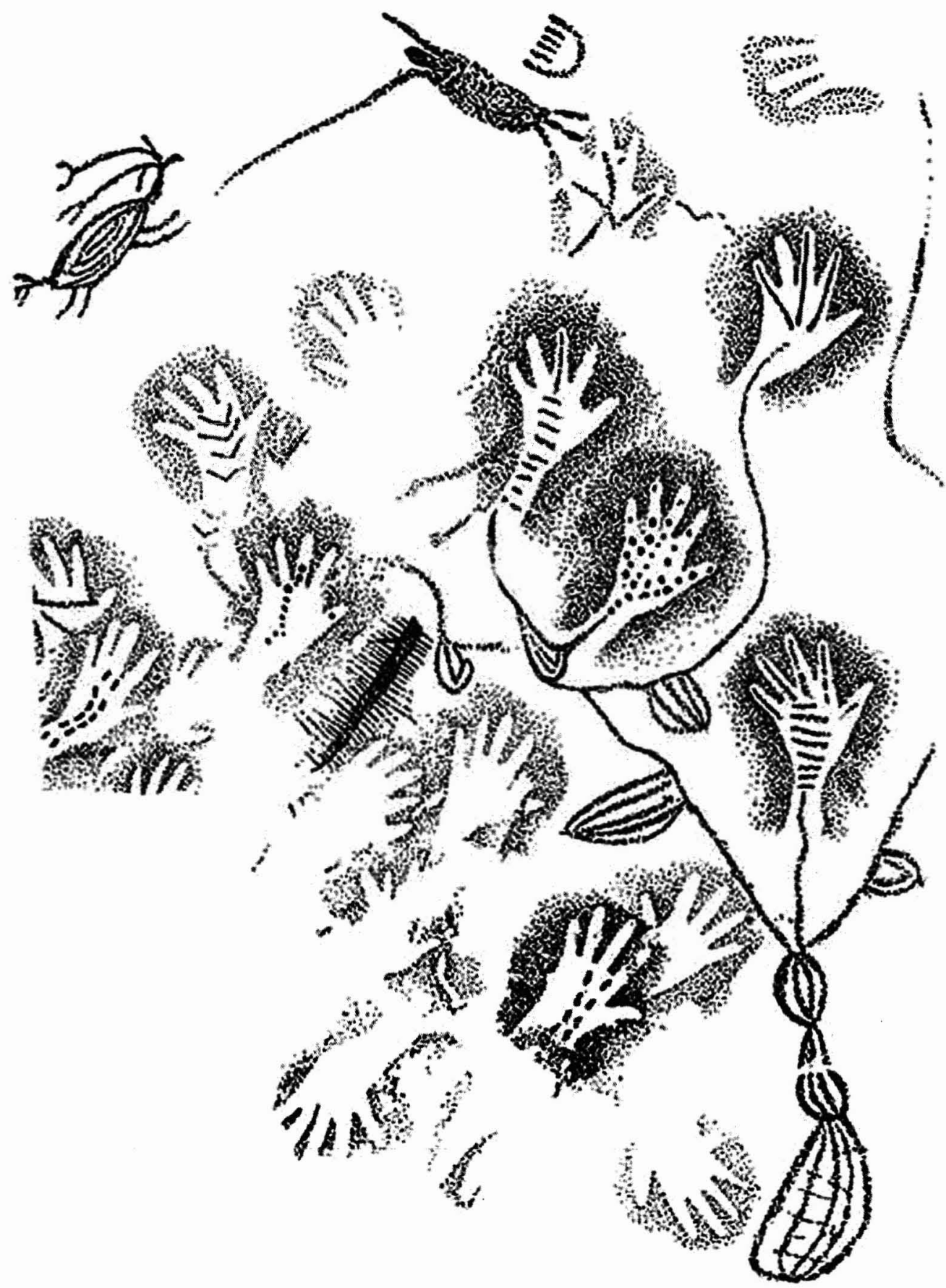

Fig. 4. Gua Tewet: panel of hand stencils in the form of a "life tree." (Recorded by L. H. Fage) 


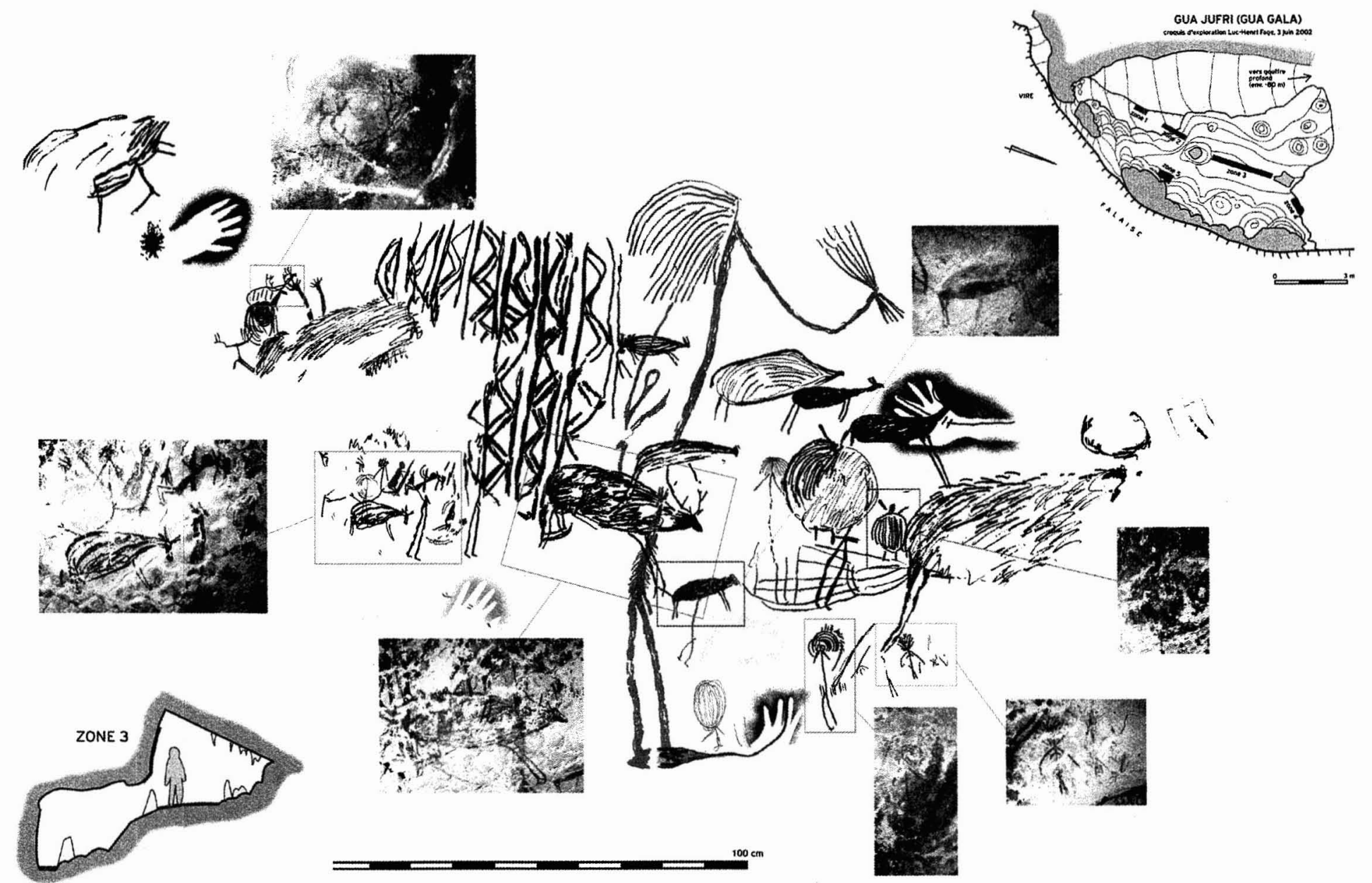

Fig. 5. Gua Jufri: paintings showing anthropomorphic and zoomorphic motifs, with peripheral hand stencils. (Recorded by L. H. Fage) 
sometimes had an essentially symbolic meaning or function, including (or expressing) sociocultural intentions, whereas at other times they may have been linked more to the natural environment or to practical preoccupations. Some panels that appear to show animals and humans involved in hunting, dancing, fighting, or any other activities are more expressive, figurative, and realistic. Most of the groups of hand stencils are located in peculiar places: very visible shelters or hollows, ridges, overhangs, or high on the walls or ceilings, like the clusters on the ceilings of Gua Ilas Kenceng and Gua Ham, respectively 8 and $14 \mathrm{~m}$ above the cave floor (Fig. 6).

The scenes showing human beings scattered or associated with hand stencils are reminiscent of other systems of prehistoric rock art elsewhere in the world, but do not have any obvious link with the recent indigenous cultures of the region, except in the sense that wooden sculptures were used for symbolic purposes in some ceremonies. One of the special features of the East Borneo corpus of rock art is the forceful drawings of human stick figures seemingly wearing headdresses on or around their heads - they could represent realistic masks, long and curly hair, or indeterminate symbolic attributes. The humans may also carry what look like spears, shields, bows, or other arms. At the level of the waist, there is sometimes a classical bark belt or, if the body is naked, male sex is depicted. The fact that similar scenes and hand stencil "friezes" are found more than $100 \mathrm{~km}$ away to the northeast (in Gua Mardua) suggests that the prehistoric populations in that part of Borneo shared in widespread sociocultural linkages.

\section{FUNERARY SITES}

Three of the Marang River caves appear to have been used specifically as funerary sites. They are located at middle elevations in the cliff faces, midway between the foot of the cliffs and the elevations where the painted caves are found. They are characterized by broken potsherds and human bones scattered on the ground in varying quantities, usually at the foots of walls, in flat places, or inside recesses. Many sherds are decorated, the motifs on the pots including the whole range known all over Southeast Asia: cord impressions and geometrical and curvilinear incisions, as well as punctuations and stamps. The shapes of some of the pots are similar to those of Neolithic funerary vessels found at sites such as the Niah caves and Gua Sireh in Sarawak (Datan 1993; B. Harrisson 1967), Madai (Bellwood 1988) and Baturong in Sabah (Harrisson and Harrisson 1971), or even Tabon in Palawan (Fox 1970). The fact that similar forms of Neolithic pottery would appear to have been used throughout Borneo suggests that the origins of this tradition may be more complex than the accepted model of a north coastal colonization of sea-borne Austronesians. The occupation periods indicated by the different styles of the pottery range from ca. 3500-3000 to 2500-1500 years ago. The latest period is confirmed by the finding of some bronze artifacts such as axes, spatulas, rings, and wristbands; the shape of the axes is similar to those found in Sarawak thought to come from Thailand (Higham 1989). The material suggests that Dayak or culturally similar communities settled long enough in the area to be able to maintain long-lasting cemeteries in particular selected locations such as these caves.

The Marang River fieldwork has not only located larger and more varied 


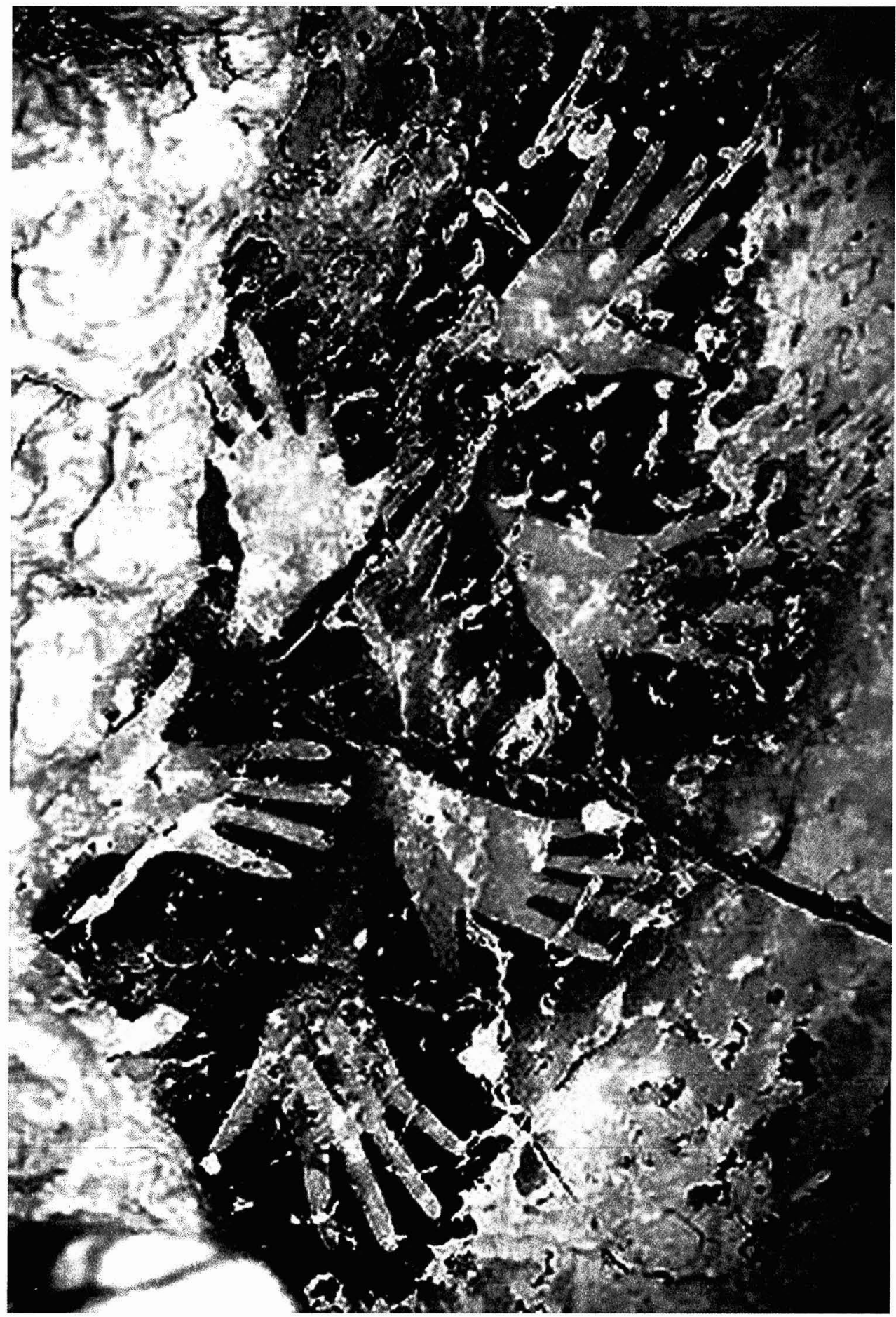

Fig. 6. Gua Ilas Kenceng: cluster of hand stencils on a ceiling $8 \mathrm{~m}$ high. (Recorded by L. H. Fage) 
samples of prehistoric pottery than we have obtained previously, but also found larger and much better-preserved sherds. The implication appears to be that these caves have not been visited much or disturbed by recent foraging populations (and today the local communities have mostly drifted to the coast in response to the activities of logging companies and the centralizing policies of the Indonesian government). For the first time, we were lucky enough to discover a couple of almost complete vessels and jars containing crushed or cremated human bones. In two small and particularly remote galleries we found incised burial jars complete enough to be reconstructed.

Further fieldwork in 2003 (thanks to National Geographic Society granting) and 2004 has yielded two important clues regarding the different funerary uses of the intermediate caves: a large $(1 \mathrm{~m}$ high) and impressive jar with incised/ punctuated and dentate decoration was found in Liang Karim, and two burials with still-articulated bones were found in Gua Keboboh, the bodies having been buried in the fetal position, sitting or lying on their left sides. This form of burial is often taken to be pre-Austronesian in type.

\section{DOMESTIC SITES}

The third category of caves found is those containing what appear to be typical remains of domestic occupation: food refuse (animal bones and shells), chert flakes, stone tools, charcoal, and potsherds. At least four sites of this category have been located, all large, dry, flat-bottomed rock shelters at the foot of the cliffs. The fact that some sites have stone flakes, charcoal, and fragments of animal bone scattered on the surface but not potsherds hints that some of these occupations may be very early, by people characterized by no or minimal use of pottery. The lithic assemblages consist mainly of flat end-scrapers and flakes retouched on the edges and/or around their proximal extremity. Many of the simpler pieces appear to have been made opportunistically, but others are more elaborate, implying a rather precise chaine operatoire. Further research is necessary to identify the sources of the stone and establish the distances over which stone blanks or finished tools were moved. Three AMS dates are now available from Gua Tengkorak, $7200 \pm 40$ cal. B.P. (Beta Analytic 167407) $4020 \pm 50$ B.P., (Beta Analytic 197167), and $11750 \pm 50$ B.P. (Beta Analytic 197162). The thickness of the occupations, though, suggests that the caves may contain evidence for long-lived domestic use, from pre-Austronesian periods until the Dayak Iban of recent years.

\section{CONCLUSION}

The main advantage for human use of the newly discovered cluster of caves and rock shelters in East Kalimantan considered in this paper would seem to be that most of them are situated at the foot of huge cliffs at the end of a karstic massif, adjacent to a river and with extensive views of the river valley. The investigation has shown that they were used variously for paintings, burials, and habitation. It would not be surprising if specific cultural traditions linked the people using these caves. However, whether the people who used these sites for burials and habitation also made the paintings still has to be established. It is noteworthy that current research in Palawan, in the region of the Ta'ut Batu and Tabon caves, has shown that caves were used in different ways at different times, with use by early 
foraging peoples in particular being slight or ambiguous (Chazine and MacDonald 1997). Clearly, a particular focus of further research on the human use of caves in East Kalimantan will need to be an attempt to establish the antiquity and the authorship of the rock art, and its relationship if any to the Holocene uses of the caves for burials and habitation.

\section{ACKNOWLEDGMENTS}

I would like to thank the French Foreign Affairs Commission des Fouilles and the French Embassy in Jakarta, as well as Total-Indonesia and Rolex for their financial, logistic, and personal support. I would also like to thank my friend and colleague Pindi Setiawan for his constant and determining contribution, and express my gratitude to L. H. Fage, caver, photographer, enthusiastic recorder, and co-organizer of all our expeditions, who first introduced me to Southeast Asian caving and hence to cave archaeology. I am also indebted to all our guides and carriers, to the FrancoIndonesian caving teams, and to the president of the HIKESPI for their survey expeditions.

\section{REFERENCES CITED}

\section{Ballard, Christian}

1992 Painted rock art sites in western Melanesia: Locational evidence for an 'Austronesian' tradition, in Occasional AURA Papers 4:94-105, ed. J. McDonald and I. P. Haskovec. Melbourne: Aura.

Bellwood, Peter

1988 Archaeological Research in South-Eastern Sabah. Kota Kinabalu: Sabah Museum and State Archives.

Causse, Christiane, and Valerie Plagnes

2001 Peintures rupestres à Bornéo; de la radiométrie à la datation. Journal du CEA-Saclay 14:3.

Chazine, JeAn-Michel

1995 Nouvelles perspectives archéologiques à Bornéo, Kalimantan. L'Anthropologie 99(4):6770.

1999 Préhistoire: Découverte de grottes ornées à Bornéo. Archeologia 352:12-19.

Chazine, Jean-Michel, and Charles Macdonald

1997 Recherches ethnoarchéologiques et communautés montagnardes à Palawan. Paper presented at the 3rd Philippines Conference, Aix-en-Provence.

DATAN, IPOI

1993 Archaeological Excavations at Gua Sireh and Lubang Angin. Special Monograph 6. Sarawak Museum Journal 65 (n.s. 66).

FOX, ROBERT

1970 The Tabon Caves. Monograph 1. Manila: National Museum.

HARRISSON, BARBARA

1967 A classification of Stone Age burials from Niah Great Cave, Sarawak. Sarawak Museum Journal 15 (n.s. 30-31) : 549-595.

HARRISSON, TOM

1958 The Great Cave, Sarawak: A ship of the dead cult and related rock paintings. Archaeological Newsletter 6(9): 199-203.

Harrisson, TOM, and Barbara Harrisson

1971 The Prehistory of Sabah. Kota Kinabalu (Sabah): Sabah Society.

Higham, Charles

1989 The Archaeology of Mainland South East Asia. Cambridge: Cambridge University Press.

Perrette, Yves, and Pierre De Koninck

2001 Observations géomorphologiques et biologiques dans les grottes de Marang, East Kalimantan. Unpublished report. Fédération Française de Spéléologie, Lyon. 
SOLHeim, WILHeIM G. II

1983 Archaeological research in Sarawak, past and future. Sarawak Museum Journal 50 (n.s. 29) : 35-56.

\begin{abstract}
This paper presents a brief summary of a program of study of the archaeology of caves and rock shelters in East Kalimantan, especially the results of recent fieldwork along the Marang River. The caves and rock shelters cluster into three groups in terms of their elevations in the karstic landscape and their archaeological remains. The highest and most inaccessible caves are the locations of rock paintings. Caves at middle locations have produced evidence for funerary activity. Large, dry rock shelters, mostly flat-bottomed, at the foot of the cliffs were preferred for habitation. The paintings consist especially of hand stencils but also include anthropomorphic and zoomorphic figures as well as other motifs. A stalactite date indicates that the earliest hand stencils may predate ca. 10,000 B.P., and drawings of what may be extinct animals suggest that some of the other motifs could be of such antiquity. The funerary material includes both pottery similar to Neolithic material elsewhere in Borneo and also later material associated with bronze artifacts. Some of the habitation sites may be pre-Neolithic on the evidence of multiple AMS dates between 4000 and 11750 B.P.; others are more recent. A particular focus of further research will need to be an attempt to establish the antiquity and the authorship of the rock art, and its relationship, if any, to the Holocene uses of the caves for burials and habitation. KEYWORDS: Kalimantan, Borneo, rock art, cave burial, cave habitation.
\end{abstract}

